\title{
Evaluation of Black Polyethylene Plastic Mulch for Tomato Production in Puerto Rico
}

\author{
H. Irizarry, H. Azzam, and R. Woodbur'y
}

INTRODUC'TION

Weeding is considered one of the most costly items in tomato production in Puerto Rico. Hand-weeding is still the most common practice used by the majority of the small growers, especially in areas where topography does not facilitate the use of machinery. Cultivation machines are used by only a few growers who operate on suitable land and on a large scale, and chemical weed control is not practiced yet.

Other evidence from the literature emphasizes that black mulching supresses weed growth $(5,7),{ }^{2}$ increases tomato yield $(2,8,4,7)$, reduces the incidence of soil fruit rot $(5,7)$, and affects soil temperature (6).

To test these possibilities in the Tropics a preliminary study was conducted to determine the economic use of black polyethylene plastic for tomato production.

\section{MATERIALS AND METHODS}

An experiment was conducted at the Solis Farm of the Agricultural Experiment Station, University of Puerto Rico, on February 1959, in a Vega Alta sandy clay with $\mathrm{pH}$ of 6.2 .

To facilitate drainage, ridged rows were made 4 feet wide and 30 feet long. Each plot consisted of 10 plants spaced 3 feet apart in the center of the row.

Four mulching treatments and five varieties (P.R. 123 and P.R. 126 are breeding lines developed by Dr. H. Azzam), were used in a randomized block design with four replicates. The mulching treatments were as follows: 1 . Mulching, no staking, no weeding; 2 . no mulching, no staking, weeding; 3 . no mulching, no staking, no weeding; 4 . no mulching, staking, weeding.

The black polyethylene plastic used in mulching treatment 1 was 4 feet wide and 1.5 mil ( 0.0015 inch) in thickness. It was placed over the ridged rows by hand and held in place with $U$-shaped pieces of wire attached to the edges of the film. A circular piece about 6 inches in diameter was cut from the plastic at the position where the seedlings were set in the row

1 Assistant Plant Breeder, Plant Breeder (deceased), and Taxonomist, respectively, Agricultural Experiment Station, Mayagüez Campus, University of Puerto Rico, Río Piedras, P.R.

2 Italic numbers in parentheses refer to Literature Cited, p. 63. 
(fig. 1). In treatments 2 and 4 weeding was done by hand. The cost of weeding and laying the plastic, plus that of the material, were recorded for each treatment. In this way the total cost of weeding and mulching an acre of tomatoes was estimated.

Weeks observed in treatment 3 were identified; in treatment 4 plants were grown unpruned on supported bamboo stakes.

The tomato varieties tested were the following:

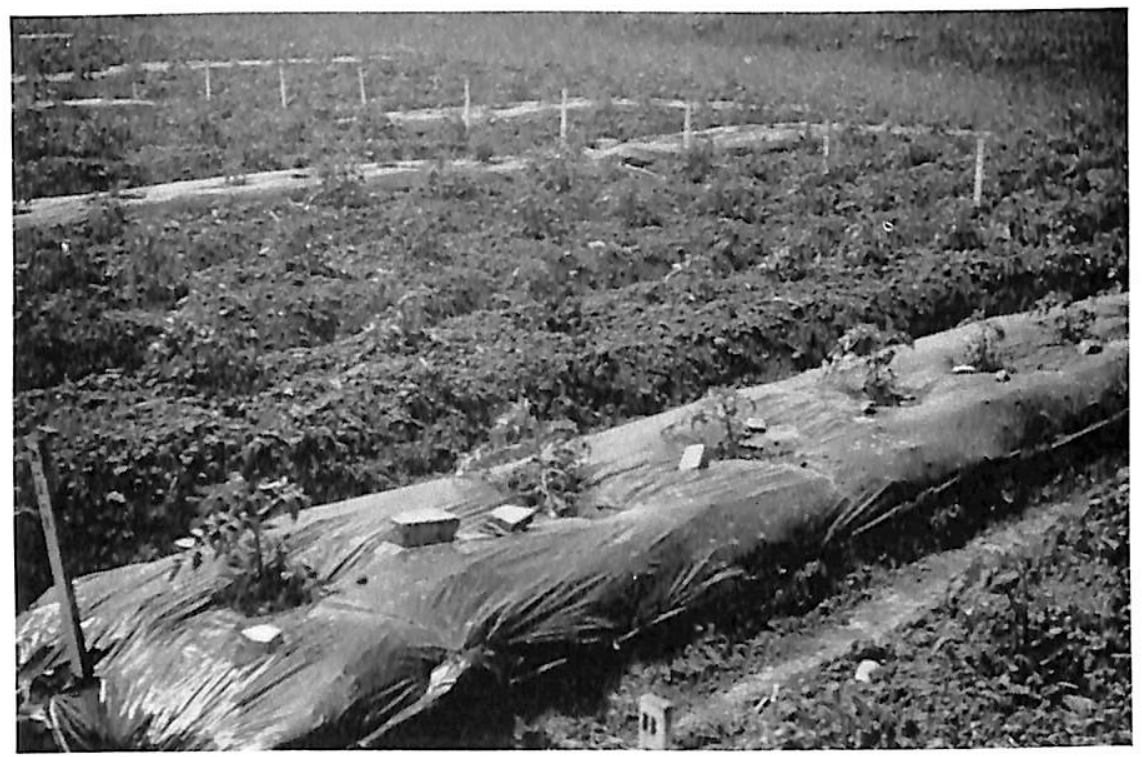

FIG. 1.-Black polyethylene mulch over ridged tomato rows.

Rutgers-A well-known indeterminate variety with vigorous vines, producing large, deep-red fruits somewhat globose in shape.

Platillo-A native indeterminate variety having large fasciated fruits very high in acid content, used primarily for cooking.

Plamar-Vigorous indeterminate plants bearing medium-sized fruits susceptible to cracking. This variety was developed by the Station from a Platillo $x$ Marglobe cross.

P.R. 123-An indeterminate, highly productive local breeding line producing medium to large fruits, whit ish in color when immature.

P.R. 126-Another highly prolific local breeding line with determinate growth, having medium to large fruits with green shoulders when mature.

Seedbeds were prepared in steam-sterilized soil in the greenhouse, and seedlings were set in the field 4 weeks later; a starter solution was used at planting time. Filter-press cake was applied in each planting hole at a rate 
of 1 ton per acre, and 9-10-5 NPK fertilizer was applied in the same manner at the rate of 1,200 pounds per acre.

Water was supplied whenever necessary to individual plants by means of a watering can. Air and soil temperature (at 2 to 4 -inch depth) and rainfall were recorded throughout the experiment. ${ }^{3}$ Control of insects and diseases were maintained by regular spraying programs. Fruits were harvested at the pink to full stage of color development.

\section{RESULTS}

The mulched plots (treatment 1), were completely free from weeds, except for nutgrass (coqui), Cyperus rotundus, L. In the unmulched, unweeded plots (treatment 3), 103 weed species were identified as shown in the following tabulation:

Weeds observed in a tomato field at Solis Farm, Rio Piedras, P.R., February-May, 1959

Fam. Gramineae

Axonopus compressus (Sw.) Beauv.-Yerba alfombra

Chloris inflata Link-Paraguita

Chloris radiata (L.) Sw.-Horquetilla

Cynodon dactylon (L.) Pers.-Pata de gallina

Digitaria sanguinalis Scop.-Pendejuelo

Echinochloa colonum (L.) Link.-Arrocillo

Eleusine indica (L.) Gaertn.-Pata de gallina

Panicum fasciculatum $\mathrm{Sw}$.

Panicum maximum Jacq. - Yerba de Guinea

Paspalum fimbriatum H. B. K.-Pata de conejo

Paspalum paniculatum L.-Yerba Venezuela

Setaria geniculata (Lam.) Beauv.-Rabo de zorro

Fam. Cyperaceae

Cyperus ferax L.

Cyperus rotundus L.-Coqus

Dichronena ciliata Vahl.-Yerba de estrella

Fam. Commelinaceae

Commelina diffusa Burm. f.-Cohitre

Fam. Amaranthaceae

Achyranthes asperal L.-Anamú, rabo de ratón Alternanthera sessilis (L.) R. Br.-Sanguinaria Amaranthus dubius Mart.-Blero

\footnotetext{
3 A Bacharach Temperature Recorder was used for soil temperature. Trade names are used in this publication solely for the purpose of providing specific information. Mention of a trade name does not constitute a guarantee, warranty, or endorsement by the Agricultural Experiment Station indicating superiority to other similar products not mentioned.
} 
Amaranthus spinosus L.-Blero espinoso

Gomphrena dispersa Standley-Siempreviva silvestre

$$
\text { Fam. Nytaginaceac }
$$

Boerhaavea coccinea Mill.-Tostón

Boerhaavea erecta L.-Tostón

Fam. Aizoaceae

Trianthelma portulacastrum L.-Verdolaga

Fam. Alsinaccae

Drymaria cordala (L.) Willd.-Drimaria, yerba de estrella

Fam. Portulacaceae

Portulaca oleracea L.-Verdolaga

Fam. Papaveraceae

Argemone mexicana L.-Cardo santo

Fam. Capparidaceae

Cleome spinosa Jacq.-Volantines preciosos

Fam. Momosoideae

Aeschynomene americana Sw.-Moriviví bobo

Aeschynomene sensitiva Sw.-Moriviví bobo

Mimosa pudica L.-Moriviví

Fam. Caesalpinioideae

Cassia aeschynomene DC.-Moriviví bobo

Cassia occidentalis L.-Hedionda

Cassia tora L.-Dormidera

Fam. Papilionoideae

Centrosema pubescens Benth.-Flor de pito

Crotalaria retusa L.-Matraca, sonajuelas

Crotalaria striata L.-Matraca, sonajuelas

Desmodium supina DC.-Cadillo pegajoso

Dolicholus minimus (L.) Medic.-Frijolillo

Indigofera endecaphylla-Añil rastrero

Phaseolus lathyroides L.-Habichuela parada

Vigna repens (L.) Kuntze-Frijol silvestre

Vigna vexillata (L.) A. Rich.-Frijol cimarrón

Fam. Oxalidaceac

Oxalis corniculata L.-Vinegrillo

Oxalis martiana Zucc.-Vinegrillo morado

Fam. Zygophyllaccae

Kallstroemia maxima (L.) T. \& C.-Verdolaga de abrojo 
Fam. Polygalaceae

Polygala paniculata L.-Orosne

Fam. Euphorbiaceae

Caperonia palustris (L.) St. Hil.-Sacatrapo

Croton lobatus L.-Croton lobulado

Chamaesyce hirta $\left(\boldsymbol{L}_{\text {.) }}\right.$ Small-Lechecillo

Chamaesyce hypercifolia (L.) Small-Lechecillo

Chamaesyce prostrata (L.) Small-Lechecillo

Jatropha gossypifolia L.-Túa-Túa

Phyllanthus lathyroides L.-Quinino de pobre

Fam. Euphorbiaceae

Phyllanthus niruri L.-Quinino de pobre

Poinsettia heterophylla (L.) Kl. \& Garcke-Lechecilla

Poinsettia geniculata (L.) Kl. \& Garcke-Lechecilla

Ricinus communis L.-Higuereta

Fam. Malvaceae

Malachra capitata L.-Malva

Sida carpinifolia L.-Escoba

Sida rhombifolia L.-Escoba

Urena lobata L.-Cadillo

Urena trilobata Vahl.-Cadillo

Fam. Sterculiaceac

Melochia pyramidale (L.) Bri.-Bretónica piramidal Waltheria americana L.-Basora prieta

Fam. Onagraceae

Jussiaea angustifolia Lam.-Yerba de cigarro

Fam. Umbelliferae

Eryngium foetidum L.-Culantro

Fam. Loganiaceae

Spigelia anthelmia L.-Lombricera

Fam. Asclepiadaceac

Asclepias curassavica L.-Plantanillo

Fam. Convolvulaceae

Ipomoea polyanthus R. \& S.-Aguinaldo amarillo Ipomoea quinquefolia L.-Batatilla blanca

Ipomoea rubra (Vahl.) Milisp.-Bejuco de puerco Ipomoea tiliacea (Willd.) Choisy-Bejuco de puerco

Fam. Boraginaceae

Heliotropium indicum L.-Cotorrera 
Fain. Verbenaceae

Valerianoides jamaicensis (L.) Kuntze-Verbena

Fam. Labiatae

Hyptis capitata Jacq.-Botoncillo negro

Hyptis pectinata (L.) Poit.-Marubio falso

Leonotis nepetaefolia (L.) R. Br.-Botón de cadete

Leonurus sibiricus L.-Agripalma

Fam. Solanaceae

Physalis angulata L.-Sacabuche

Physalis turbinata L.-Sacabuche

Solanum caribaum Dunal-Mata gallina

Solanum torvum Sw.-Berenjena cimarrona

Fam. Scrophulariaceac

Capraria biflora L.-Te del pais

Scoparia dulcis L.-Culantrillo, Orozuz

Fain. Acanthaceae

Blechnum pyramidalum (Lam.) Urban-Yerba de papagayo

Fam. Rubiaceae

Borreria ocimoides (Burn. f.) DC.-Botoncillo Borreria verticillata (L.) Meyer.-Botón blanco Himidiodia ocimifolia (Willd.) K. Sch.-Poaya

Fam. Cucurbitaceae

Momordica balsamina L.-Cundeamor

$$
\text { Fam. Compositae }
$$

Ageratum conyzoides L.-Yerba de cabro

Bidens pilosa L.-Margarita silvestre

Brachyramous intybaceus (Jacq.) DC.

Eclipta alba (L.) Hassk.-Eclipta blanca

Emelia coccinea (Sims.) Sweet.-Clavelito colorado

Emelia sonchifolia (L.) DC.-Huye que te cojo

Leptilon pusillum (Nutt.) Britton-Pascueta

Melanthera confusa Britton-Salaillo

Parthenium hysterophorus L.-Ajenjo cimarrón

Pluchea odorata (L.) Cass.-Salvia

Senecioides cinerea (L.) Kuntze-Vernonia

Synedrella nodiflora (L.) Gaertn-Serbatana

Tridax procumbens L.-Tridax

In the weeded plots (treatments 2 and 4 ), three weedings were necessary to maintain the plots free from weeds. Estimated costs of hand-weeding and mulching are presented in table 1. 
Approximately 30,000 square feet of black polyethylene plastic are needed to cover an acre of tomatoes with similar planting distances. The wholesale local price of the plastic per square foot was 1.1 cents. At this price, the cost to cover 1 acre would be $\$ 330.00$, plus $\$ 18.15$ for the labor. The estimated cost of each weeding was $\$ 56.28$ per acre, which made a total of $\$ 168.84$ per acre.

The yield data for the treatments, disregarding varieties, shows that there were no significant differences among treatments at the 1-percent level as presented in table 2. Treatment 4 (no mulching, staking, weeding)

TABLE 1.-Estimated cost per acre of 3 hand-weeding vs. the use of black polyethylene mulch in tomato

\begin{tabular}{l|c|c|c|c}
\hline Treatment & $\begin{array}{c}\text { Time used per } \\
\text { wreeding or } \\
\text { mulching }\end{array}$ & $\begin{array}{c}\text { Cost per } \\
\text { weeding or } \\
\text { mulching }\end{array}$ & $\begin{array}{c}\text { Cost of } \\
\text { materials }\end{array}$ & Total cost \\
\cline { 1 - 3 } & Mann-hours & Dollars & Dollars & Dollors \\
Hand-weeding & 93.8 & 56.28 & - & 168.84 \\
Mulching & 30.25 & 18.15 & 330.00 & 348.15 \\
\hline
\end{tabular}

1 Based on wages paid in $1959, \$ 0.60 / \mathrm{hr}$.

2 Based on local wholesale price of 1.1 cent/sq. $\mathrm{ft}$.

TABLE 2.-Estimated yield in tons per acre of marketable tomatoes for 4 different mulching treatments at Solis Farm, Rio Piedras, P.R.'

\begin{tabular}{l|c|c}
\hline \multicolumn{1}{c|}{ Treatment } & Estimated tons per acre & $\begin{array}{c}\text { Outyielded significantly } \\
\text { at 5-percent level }\end{array}$ \\
\hline 4 No mulching, staking, weeding & 8.57 & 3,1 \\
2 No mulching, no staking, weeding & 8.20 & \\
1 Mulching, no staking, no weeding & 7.33 & \\
3 No mulching, no staking, no weeding & 7.24 & \\
\hline
\end{tabular}

${ }^{1} S_{\bar{x}}=0.347$ tons/acre. Error $d_{f}=44$

outyielded significantly treatments 1 and 3 at the 5-percent level. No significant differences between treatments 4 and 2 (no mulching, no staking, weeding) were detected.

Table 3 compares the number of fruits per 10 plants for the 5 varieties. The analysis of variance shows that P.R. 123 outyielded significantly Rutgers and Platillo with respect to the number of fruits.

Other results of the covariance analysis for the effect of plant stand on the weight and number of fruits showed: 1 , No significant effect of plant stand on differences among varieties; 2 , the variety $X$ treatment interaction was not significant; 3 , the differences among treatments with respect to number of fruits were also not significant; and 4, the differences among 
treatments with respect to weight of fruits were significant at the 5-percent level.

The air- and soil-temperature data are presented in table 4. There was no significant increase of temperature under plastic mulching when compared with bare-soil temperature at a depth of 2 to 4 inches. The maximum soil temperature registered under mulching was $100^{\circ} \mathrm{F}$. and without mulching, $96^{\circ} \mathrm{F}$. Both of these were recorded during March.

TABLE 3.-Number of fruits per 10 plants, and mean fruil weight, for 5 tomato varieties at Solis Farm, Rio Piedras, P.R.1

\begin{tabular}{l|c|c|c}
\hline \multicolumn{1}{r|}{ Variety } & Mean fruits per plot & Superior at 1 percent & Mean fruit weight \\
\hline & Number & & Pounds \\
P.R. 123 & 405 & Rutgers, Platillo & 0.135 \\
Plamar & 365 & do. & .115 \\
P.R. 126 & 331 & do. & .131 \\
Platillo & 257 & do. & .210 \\
Rutgers & 120 & & .181 \\
\hline
\end{tabular}

${ }^{1} S_{\bar{x}}=24.64$ fruits/plot. Error $d_{f}=12$

TABLE 4.-Air and soil temperature $\left({ }^{\circ} F\right.$.) recorded during the tomato-growing season, Feb. 16-May 11, at Solis Farm, Rio Piedras, P.R.

\begin{tabular}{l|c|c|c}
\hline \multirow{2}{*}{ Item } & Air temperature & \multicolumn{2}{|c}{ Soil temperature at 2-4-inch depth } \\
\cline { 2 - 4 } & & Under mulching & Without mulching \\
\hline Average minimum & $67.3^{\circ}$ & $79.5^{\circ}$ & $79.0^{\circ}$ \\
Average maximum & $87.0^{\circ}$ & $93.6^{\circ}$ & $92.2^{\circ}$ \\
Mean & $\mathbf{7 7 . 2}^{\circ}$ & $86.6^{\circ}$ & $85.6^{\circ}$ \\
Range & $62^{\circ}$ to $92^{\circ}$ & $74^{\circ}$ to $100^{\circ}$ & $74^{\circ}$ to $96^{\circ}$ \\
\hline
\end{tabular}

A total of 7.03 inches of rain were registered from February 15 to May 11, most of which fell during the harvesting season, April 20 to May 11.

\section{DISCUSSION}

Black polyethylene plastic prevented the growth of weeds in mulched tomato plots except for nutgrass, the sharp spikes of which grew through it. A thicker plastic could probably resist nutgrass puncture and subsequent growth. Despite its effectiveness in weed control, the cost of the plastic makes its commercial use prohibitive for tomato production. But, since the plastic could be removed from the field and used in one or more plantings, mulching costs could be reduced considerably.

In this experiment only three weedings were found to be necessary to 
keep the weeded plots clean. Under well-distributed rainfall, more cultivations may be necessary to maintain a tomato field free of weeds.

A significant decrease in yield was detected in the mulched plots as compared with treatment 4 (no mulching, staking, weeding), at the 5-percent level (table 2). Since the variance analysis showed no significant differences among mulching treatments with respect to the number of fruits, this yield reduction may be accounted for by the small size of the fruits instead of a reduction in the number of fruits. These results are not in accordance with previous findings $(2,3,4,7)$. Carolus et al. (2), reported that yield increase in muskmelon under plastic mulching resulted from an increase in both size and number of fruits.

McGuire (8), attributed tomato-yield increase with black plastic to a reduction in the incidence of soil fruit rot. Although this experiment was harvested during the rainy season, the total amount of rotten fruits was very low and generally uniform among treatments. However, tomato fruits picked from the mulched plots were free of soil particles.

According to these findings (table 2), there is no indication that, under our conditions, plastic mulching may replace staking in tomato production. Emmert (5), stated that black plastic was promising as a substitute for staking.

The fact that the variety $\times$ treatment interaction was not significant, indicates that none of these varieties responded to any particular treatment.

The mean soil temperature under mulching was $1^{\circ} \mathrm{F}$. higher than that of the bare soil. This temperature was $1.5^{\circ} \mathrm{F}$. lower than the one reported by Honma et al. (6), using black plastic mulching in muck soil. No rainfall was registered when the maximum high bare soil temperature was recorded, but 0.51 inch of rain was recorded when the maximum high mulched soil temperature was attained.

\section{SUMMARY}

An experiment was conducted on February 1959 to evaluate the economic use of black polyethylene mulch paper for tomato production in Puerto Rico.

Four treatments and five varieties were used in a randomized block design with four replications. The combined treatments used were described as follow: 1. Mulching, no staking, no weeding; 2 . no mulching, no staking, weeding; 3. no mulching, no staking, no weeding; 4. no mulching, staking, weeding.

The varieties included in this trial were Rutgers, Platillo, Plamar, and the local breeding lines P.R. 123 and P.R. 126.

The results of this study indicate that black polyethylene suppressed all 
weed growth except for nutgrass, Cyperus rotundus L., but its cost per acre when compared with regular weeding remained a limiting factor.

A significant decrease in yield was detected in treatment 1 when compared with treatment 4 at the 5-percent level.

Plastic mulching apparently did not have any remarkable effect in reducing the incidence of soil fruit rot. Although the experiment was harvested during the rainy season, the total number of rotten fruits was very low and generally uniform among treatments.

The fact that the variety $X$ treatment interaction with respect to the weight and number of fruits was not significant, indicated that these varieties did not respond to any particular treatment. However, the Rutgers tomato had the poorest performance of all the varieties included in this trial.

Black polyethylene increased soil temperature by $1^{\circ} \mathrm{F}$. when compared with bare soil temperature at a depth of 2-4 inches.

\section{RESUMEN}

En febrero 1959, se llevó a cabo un experimento para determinar el efecto y el valor que pueda tener una cubierta de papel negro de polietileno sobre la producción de tomates en Puerto Rico.

Se usaron cuatro tratamientos y cinco variedades en un diseño de bloque al azar con cuatro repeticiones. Los tratamientos combinados fueron como sigue:

1. Surcos cubiertos con el plástico negro, sin desyerbar, y dejando que las plantas crecieran sin soportes.

2. Surcos al descubierto, desyerbados a mano, y dejando que las plantas crecieran sin soportes.

3. Surcos al descubierto, sin desyerbar, y dejando que las plantas crecieran sin soportes.

4. Surcos al descubierto, desyerbados a mano, y dejando que las plantas crecieran con soportes.

Las variedades incluidas en este estudio fueron Rutgers, Platillo, Plamar y dos líneas desarrolladas en la Estación, P.R. 123 y P.R. 126.

Los resultados de esta prueba indican que la cubierta con el plástico negro impidió el crecimiento de todos los yerbajos, excepto el coqui, Cyperus rotunds $\mathrm{L}$., pero el costo por acre cuando se comparó con el desyerbo a mano fue un factor limitativo.

En cuanto a la producción, no se observaron diferencias significativas entre los tratamientos, al 1 por ciento del nivel de probabilidad. No obstante, se observó una reducción en la producción cuando se comparó el tratamiento 1 con el 4, al 5 por ciento de probabilidad.

Aparentemente, la cubierta plástica no tuvo efecto alguno en reducir el 
número de frutas dañadas debido al contacto con el suelo. Aunque el experimento se cosechó durante la época lluviosa, el número de frutas dañadas fue muy bajo y uniforme en todos los tratamientos.

El hecho de que la interacción entre la variedad y el tratamiento, con relación al peso y número de frutas no fue significativa, indica que ninguna de las variedades usadas en este experimento respondió a tratamiento alguno, en particular. No obstante, se observó que fue la variedad Rutgers la que menos respondió respecto a los dos caracteres mencionados anteriorormente.

La cubierta de plástico negro aumentó la temperatura del suelo en $1^{\circ} \mathrm{F}$., cuando se comparó con la del suelo al descubierto, a una profundidad de 2-4 pulgadas.

\section{LITERATURE CITED}

1. Britton, N. L., and Wilson, P., Scientific Survey of Puerto Rico and the Virgin Islands, N.Y. Acad. of Sci. 5, 6, 1925-30.

2. Carolus, R. L., and Downes, J. D., Studies on Muskmelon and Tomato Responses to Polyethylene Mulching, Mich. Agr. Exp. Sta. Q. Bul. 40: 770-85, 1958.

3. Chipman, E. W., Studies on tomato response to mulching on ridged and flat rows, Can. J. Plant Sci. 41: 10-15, 1961.

4. Clarkson, V. A., and Frazier, W. A., Plastic Mulches for Horticultural Crops, Oreg. State Sta. Bul. 562, 1957.

5. Emmert, E. M., Black polyethylene for mulching vegetables, Am. Soc. Hort. Sci. Proc. 69: 464-9, 1957.

6. Honma, S., McArdle, F., Carew, J., and Dewey, D. H., Soil and Air Temperature as Affected by Polyethylene Film Mulches, Mich. Agr. Exp. Sta. Q. Bul. 41: 834-42, 1959.

7. McGuire, D. C., tomato Yield Increased by Black Plastic Mulch, Hawaii Agr. Expt. Sta. Farm Sci. 8: 4-5, 1959 